Article

\title{
Repulsive Effect of Stroboscopic Light Barriers on Native Salmonid (Salmo trutta) and Cyprinid (Pseudochondrostoma duriense and Luciobarbus bocagei) Species of Iberia
}

\author{
Joaquim Jesus ${ }^{1,2, * \mathbb{C}}$, Amílcar Teixeira ${ }^{3}$, Silvestre Natário ${ }^{2}$ and Rui Cortes ${ }^{1}{ }^{1}$ \\ 1 CITAB, Centre for the Research and Tecnhology of Agro-Environmental and Biological Sciences, \\ University of Trás-os-Montes e Alto Douro, Quinta dos Prados, 5000-911 Vila-Real, Portugal; \\ rcortes@utad.pt \\ 2 OriginAL Solutions, Estrada do Cando, Casa da Fraga, 5400-010 Chaves, Portugal; snatario@gmail.com \\ 3 Centro de Investigação de Montanha (CIMO), Instituto Politécnico de Bragança, Campus de Santa Apolónia, \\ 5300-253 Bragança, Portugal; amilt@ipb.pt \\ * Correspondence: jjesus@utad.pt; Tel.: +351-963310059
}

Received: 30 December 2018; Accepted: 27 February 2019; Published: 4 March 2019

check for updates

\begin{abstract}
A repulsive effect, that some induced primary stimuli, like sound and light, is known to be provoked in fish behavior. In the present study, two strobe light frequencies, 350 flashes/minute and 600 flashes/minute, were tested in laboratorial conditions, using three native freshwater fish species of northern Portugal: Brown trout (Salmo trutta), Northern straight-mouth nase (Pseudochondrostoma duriense) and Iberian barbel (Luciobarbus bocagei). The results showed a differential repulsive behavior of the fish species to light stimulus, and particularly to a frequency of 600 flashes/minute. S. trutta presented the most repulsive behavior, whereas the L. bocagei showed less repulsion to the light stimulus. No relevant differences were found between pre-test and post-assessments, confirming a rapid recovery of natural fish behavior after the deterrent effect. The results highlighted the potential of behavioral barriers, particularly in salmonid streams, based on strobe light stimulus.
\end{abstract}

Keywords: underwater light; behavioral barriers; brown trout; endemic cyprinids; deterrent effect

\section{Introduction}

Mediterranean freshwater ecosystems and particularly native fish are severely threatened by human activities, such as river regulation, responsible for dramatic habitat modifications [1], leading to the reduction of habitats (e.g., breeding, feeding, and shelter) and increased biotic interactions (e.g., competition and predation) with the non-indigenous species [2]. In Iberia, a large number of small and large dams are responsible for the disruption of river connectivity, which can directly affect fish movements. The migratory reproductive routes of diadromous and inclusively potamodromous species to the spawning habitats are inhibited, with consequences for their survival [3,4], as well as the interruption of the migrations downstream of the cyprinids have great importance in the life cycle of these fish, especially in the trophic and refuge migrations [5-7]. Other movements of Iberian cyprinids, often in the downstream direction, may result also from severe droughts, where fish may look for refuge in pools with favorable morphological and physicochemical conditions, namely well-developed canopies [8]. The existence of certain barriers becomes a serious handicap for their survival. According to the Red Book of the Portuguese vertebrates [9], 69\% of native freshwater fish species are extremely vulnerable, justifying the development of in-situ conservation measures. 
Native salmonid (S. trutta) and cyprinid (L. bocagei, P. duriense) species of northern Iberia have higher displacements along the river, namely during the potamodromous reproductive seasons, and their interest for conservation (e.g., threatened populations) and exploitation (e.g., angling activity) purposes is relevant for different management plans. Furthermore these species show a vulnerability in River Douro catchment: Trout is restricted to the upper part of a few tributaries [10], negatively impacting the upstream and downstream movements [11], whereas the other two cyprinids are strongly impacted by regulation, coupled with the natural wide variability of flow, common in the Iberian Peninsula [12,13]. Moreover, Iberian rheophilic cyprinids have exigent habitat requirements [12], and frequently make displacements especially in spawning activity, during which they have to find well-oxygenated gravel-bed spawning areas but also to complete their life cycle [14].

Baras and Lucas [3] state that in regulated rivers, spawning grounds (breeding migrations upstream) and feeding and sheltering sites (trophic migrations downstream) can be at great distances, forcing these species to migrate further and further away. The authors concluding that potamodromy may correspond to an adaptive response for these species.

However, these movements are highly conditioned by the presence of obstacles, and high fish mortalities has been registered [15,16]. Abrupt changes in pressure, cavitation, shear forces, turbulence, and mechanical shock are some of the effects experienced by fish in the adduction to the hydroelectric turbine [17-19]. For these reasons, deterrent systems have been used in different management applications and physical and nonphysical barriers developed to prevent fish from spreading or to guide fishes away from sources of mortality $[4,20,21]$.

Non-physical barriers can use behavioral and/or physiological stimuli to control fish movements, since fish may exhibit attraction or repulsion behavior, caused by various environmental stimuli including sound $[15,22,23]$, light $[20,21,24,25]$, electric [26,27], chemical [28,29], and mixed [30,31]). The efficiency of these non-physical barriers depends on the fish species, the environmental conditions, and the potential habituation to a particular stimulus $[32,33]$.

Light has been used over the centuries, both as a repulsive/attractive stimulus, for fish, and other aquatic animals [4]. Luminous stimuli are particularly important to fish because they use vision for food, reproduction or to avoid predation, and responses to light are therefore crucial for their survival [34]. The use of strobe light on behavioral barriers for fish has demonstrated repulsive efficiency with some species, and at various tested frequencies [29,35-37]. However, even if there are studies concerning the movements of Iberian rheophilic cyprinids, they are limited to the influence of environmental factors on longitudinal displacements in rivers (e.g., Lucas \& Baras [7]; Ovidio et al. [38]; Benitez \& Ovidio [39]), and not to laboratory conditions to determine deterrent effects that can be transposed to natural conditions, in order to mitigate the effect of obstacles. Only the particular case of hydropeaking has been recently subject to indoor flume tests in Iberian barbel [40]. It is, therefore, an unprecedented study of great relevance, since the applied knowledge resulting from these experiments can contribute to the protection and safeguarding of these species through the deterrent effects of these stimuli on fish, avoiding their access, for example, to electric production turbines (upstream dam), pumping systems (downstream dam), and adductor systems, thereby reducing their mortality rate caused by the physical impacts typical of those structures [15]. Different light barriers had been used to protect native fish populations by re-routing them to the proper passages in hydroelectric power plants [41], and to avoid or, at least, slow down the spread of invasive non-indigenous species [4,42-45].

The main objective of the present study was to evaluate the repulsive behavioral response, in laboratory conditions in three native freshwater species of Northern Portugal: Brown trout (S. trutta), a salmonid species, and two endemic cyprinids, Northern straight-mouth (P. duriense), and Iberian barbel (L. bocagei), exposed to two stroboscopic light frequencies, either in day and night periods. We hyphotetyze for different reactions considering the specific vision and trophic factors, characteristics of each taxa. 


\section{Materials and Methods}

\subsection{Study Site}

The study took place in the fish farm facilities of governmental services, the Portuguese Conservation of Nature and Forest Institute (Posto Aquícola de Castrelos) in northeastern Portugal, which took place between May 2011 to December 2014. The laboratorial recirculating tanks were used to develop the experiments, supplied with a good water quality from a headstream, the River Baceiro. During experiments. The water temperature ranged from 14 to $16^{\circ} \mathrm{C}$ and a high dissolved oxygen concentration $\left(>9.0 \mathrm{mg} \cdot \mathrm{L}^{-1}\right)$ was maintained in the laboratorial tanks.

\subsection{Target Species}

Three native species of the Douro basin, S. trutta, P. duriense, and L. bocagei were used in the tests with the following biometric data: [Total length TL: mean \pm SD (cm); Mass M: mean \pm SD (g))]: (1) S. trutta-TL: $16.1 \pm 2.3 \mathrm{~cm}$; M: $59.2 \pm 23.9 \mathrm{~g}$; (2) P. duriense-TL: $12.4 \pm 3.2 \mathrm{~cm}$; M: $21.7 \pm 11.6 \mathrm{~g}$; and (3) L. bocagei-TL: $12.9 \pm 2.5 \mathrm{~cm}$; M: $32.8 \pm 23.1 \mathrm{~g}$. The fish were captured by electrofishing (Hans Grassl ELTII, DC 300/600 V) in the River Sabor (Douro basin) and transported in appropriated conditions of low temperature $\left(\mathrm{T}<16{ }^{\circ} \mathrm{C}\right.$ ) and oxygenation ( $\left.\mathrm{DO}>9.0 \mathrm{mg} \mathrm{O} \cdot \mathrm{L}^{-1}\right)$. Before the experimental trials, fish spent a quarantine week, after which they were distributed separately by different maintenance tanks, under similar water quality conditions with the test tank until the beginning of each trial ( 2 to 3 weeks). After the tests, the captured fish were in good health and were released in the same area of the river where they had been previously captured.

\subsection{Test Stimuli}

The trials were carried out under laboratory conditions and discriminated by each species, considering a group of 20 individuals replaced at each trial. To evaluate the reaction of fish it was induced a strobe stimuli: 350 flashes/minute, with opening of $30 \mathrm{~ms}$ and $9841 \times$ for the daytime period and $7391 \times\left(1 \mathrm{l} \times=1 \mathrm{~lm} / \mathrm{m}^{2}\right)$ for the night period and 600 flashes $/ \mathrm{min}$ with aperture of $30 \mathrm{~ms}$ and $12261 \times$ for the daytime period and $7391 \times$ for the night period. Lux values were recorded underwater (0.3 m distance) with Lux Meter RS-PRO Model 180-7133 with an accuracy of 4\%.

\subsection{Experimental Design}

Experimental rectangular test tanks, with dimensions of $1.5 \times 1.0 \times 0.5 \mathrm{~m}$ and a capacity of $750 \mathrm{~L}$ were used, with oxygenation system and temperature control. The walls of the tanks, with the exception of the strobe lamp window, were coated with black matte paper and by avoiding visual influences from outside. The placement of a central black span (Figure 1) $0.70 \times 0.36 \times 0.45 \mathrm{~m}$, served to promote the circular movement of fish. To create the adequate water flow conditions in the tanks $\left(30 \mathrm{~L} \cdot \mathrm{min}^{-1}\right)$, a distributed pumping system was fitted and adjusted to the available internal space in order to stimulate the rheophilic behavior of these species. Each aquarium was equipped with a strobe light placed in the middle of one of the lateral corridors, where the fish counting line was defined (Figure 1). The test tanks were equipped with two video cameras (Model Sony 600TVLines, underwater camera), involving an infra-red system for night recording of fish movement. One of the video cameras (video 1-Figure 1) was placed just above the counting line, thus allowing a recording of the passage of the fish. The second video camera (video 2-Figure 1) was placed close to the test tank, allowing a more comprehensive video recording of the entire tank (Figure 1). 


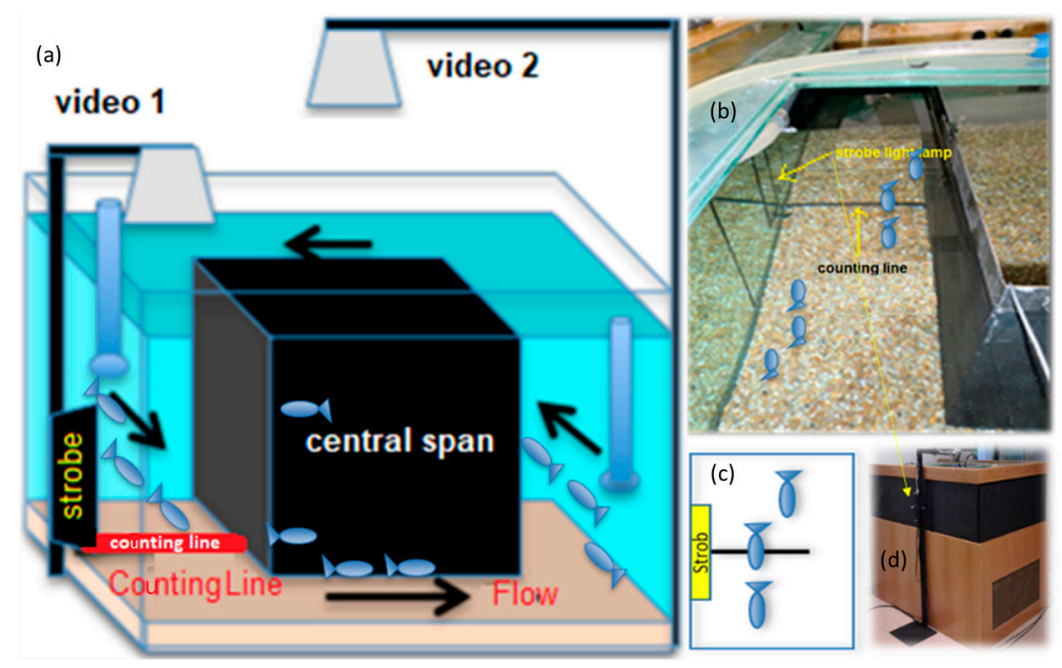

Figure 1. Design and conceptual model of the laboratorial test tank: (a) Functional diagram; (b,c) Counting line; (d) Test tank.

The same tests were performed for each target species, using the two mentioned frequencies during both nocturnal and diurnal periods. Each fish group (20 individuals) was placed in the aquarium two hours before starting each test for proper acclimation. The trials lasted for $130 \mathrm{~min}$, corresponding to $60 \mathrm{~min}$ of pre-test (strobe light off), $60 \mathrm{~min}$ of Test (strobe light on), and $10 \mathrm{~min}$ of Post assessment (strobe light off). For each species and frequency tested (350/600), 3 replications were performed, both in the daytime and at night, totaling 36 trials for the three species (720 fish). The efficacy of each frequency was checked by video analysis and by direct observation of fish passages at the counting line, by comparing the means of the number of passages of the pre-test (strobe light off) to the means of the number of passages of the treatment test (strobe light on). Fish were counted each minute by freezing the video images, resulting in counts accumulated of $5 \mathrm{~min}$. Data were organized in 12 periods of $5 \mathrm{~min}$, completing the hour of pre-test and treatment tests. For post assessment tests only 2 periods of $5 \mathrm{~min}$ were considered. Through the comparative analysis between the counts obtained in the pre-test, and test, the behavioral response of each species was analyzed.

The relative efficiency corresponds to the fraction (percentage) that was affected repulsively by each the strobe light stimulus, and was calculated according to the following formula:

$$
\text { Relative efficiency }(\%)=\left(1-\left(\frac{\text { no. fishes counting line }- \text { tests }(\text { strobe on })}{\text { no. fishes counting line }- \text { pre-tests }(\text { strobe of })}\right)\right) \times 100
$$

\subsection{Statistical Analysis}

The statistical analyses were initially performed using the Shapiro-Wilk procedure to test if data had a Gaussian distribution and by the Bartlett test to verify the homogeneity of variance. Since normality assumptions were not verified, no parametric tests were applied.

In the first test, a 2-way permutational multivariate analysis of variance (PERMANOVA) (type-III) was conducted, which was applied to the overall data (involving simultaneously day and night periods), considering the following factors: Stroboscopic light effect (2 levels: off and light stimuli), light frequencies (2 levels: 350 flashes/min and 600 flashes/min), and fish species (3 levels: S. trutta, P. duriense, and L. bocagei) all fixed factors used to assess the effect of each variable on the deterrent behavior response. The analysis included a random factor with different sets of fishes tested (6 levels). It used a balanced cross-design of the fixed factors. Additional PERMANOVA pairwise comparisons were used to statistically analyze the reaction of fish species. These computations are based on a similarity matrix using Euclidean distances. 
In the second approach a 3-way PERMANOVA (type-III) was used for each fish species, taking into account the following factors: Stroboscopic light effect (2 levels: off and light stimuli), light frequencies (2 levels: 350 flashes/min and 600 flashes/min), and day period (2 levels: day and night), as fixed factors, in order to verify the individual fish species responses.

All PERMANOVAs were performed with 999 permutations on the basis of Euclidean distances (Anderson 2001). PERMANOVAs were computed with PRIMER 7 \& PERMANOVA+ (Primer-E, UK) for Windows.

\section{Results}

The global results of 2-way PERMANOVA showed a significant effect of the stroboscopic light $(p<0.01)$ and of the fish species $(p<0.01)$, but not of frequency type $(p>0.05)$. Only the interaction between species and the considered assemblages was significant $(p<0.05)$. The pair-wise tests for fish species allowed significant differences $(p<0.05)$ between $S$. trutta and L. bocagei and between P. duriense and L. bocagei to be determined, but not between S. trutta and P. duriense.

Based on the 3-way PERMANOVA tests developed for each fish species, it was possible to highlight the following results: (1) S. trutta- the light effect (Pseudo $\mathrm{F}=22.89, p<0.001$ ) and light frequencies (Pseudo $\mathrm{F}=3.46, p<0.05$ ) effects were significant; (2) P. duriense- only light effects (Pseudo $\mathrm{F}=6.84, p<0.01$ ) were significant; (3) L. bocagei- no significant differences were detected.

S. trutta appeared to be more sensitive to light stimulus comparatively with both endemic cyprinid species (Table 1). The relative efficiency was indeed more effective for $S$. trutta during the day, with $88 \%$ (600 flashes $/ \mathrm{min}$ ), 77\% (350 flashes/min). The relative efficiencies between both cyprinid species were also distinct. The L. bocagei exhibited the lower deterrent effect relatively to the stroboscopic light effect, since the relative efficiencies were on average, and during day and night periods, only near $28 \%$, and $25 \%$, respectively, while for P. duriense these values were always above $40 \%$, reaching $64.5 \%$ for 350 flashes $/ \mathrm{min} /$ night (Table 1). Extract of video that shows the behavior of the fishes (trout in $600 \mathrm{flashes} / \mathrm{min} /$ day and nase 350 flashes/min/night) with the beginning of strobe stimulus can be seen in the "Supplementary Material".

Table 1. Relative efficiency (\%) of the various stimuli tested in S. trutta, P.duriense and L. bocagei.

\begin{tabular}{|c|c|c|c|c|c|}
\hline \multirow[t]{2}{*}{ Specie (dates) } & \multirow[t]{2}{*}{ Trial } & & \multicolumn{2}{|c|}{$\begin{array}{l}\text { Counting Line }{ }^{1} \\
\left(n^{\circ} . \text { of fishes }\right)\end{array}$} & \multirow[t]{2}{*}{$\begin{array}{c}\text { Relative } \\
\text { Efficiency (\%) }\end{array}$} \\
\hline & & & Pre-test & Testing & \\
\hline \multirow{4}{*}{$\begin{array}{c}\text { S. trutta } \\
(19 / 5 / 2011-8 / 8 / 2011)\end{array}$} & \multirow{2}{*}{350 flashes/min } & Day & 2354 & 535 & 77.27 \\
\hline & & night & 1606 & 819 & 49.00 \\
\hline & \multirow{2}{*}{600 flashes $/ \mathrm{min}$} & day & 1558 & 189 & $87.87^{2}$ \\
\hline & & night & 1328 & 437 & $67.09^{3}$ \\
\hline \multirow{4}{*}{$\begin{array}{c}\text { P. duriense } \\
(13 / 6 / 2011-8 / 7 / 2011)\end{array}$} & \multirow{2}{*}{350 flashes $/ \mathrm{min}$} & day & 2329 & 1376 & 40.92 \\
\hline & & night & 2273 & 374 & 64.50 \\
\hline & \multirow{2}{*}{600 flashes $/ \mathrm{min}$} & day & 3156 & 1298 & 58.87 \\
\hline & & night & 1740 & 975 & 43.97 \\
\hline \multirow{4}{*}{$\begin{array}{c}\text { L. bocagei } \\
(16 / 6 / 2011-10 / 7 / 2011)\end{array}$} & \multirow{2}{*}{350 flashes/min } & day & 2538 & 1822 & 28.21 \\
\hline & & night & 2466 & 2176 & 11.76 \\
\hline & \multirow{2}{*}{600 flashes $/ \mathrm{min}$} & day & 2428 & 1771 & 27.06 \\
\hline & & night & 2055 & 1529 & 25.60 \\
\hline
\end{tabular}

${ }^{1}$ Average of counted fish in the 3 repetitions, in each trial; ${ }^{2}$ Maximum day; ${ }^{3}$ Maximum night.

Figure 2 shows the time sequence of the fish counts (mean values - counting line) in each of the three trail tests for S. trutta and P.duriense: Pre-test treatment -and post-assessment tests. It should be noted that, after the light stimuli of the treatment tests (strobe light on), the fish species behavior during the post-assessment tests were similar to the behavior observed in the pre-test periods. The L. bocagei 
were not considered for this graphical presentation because it did not show significant repulsive behavior (relative efficiency values always lower than $30 \%$ ).

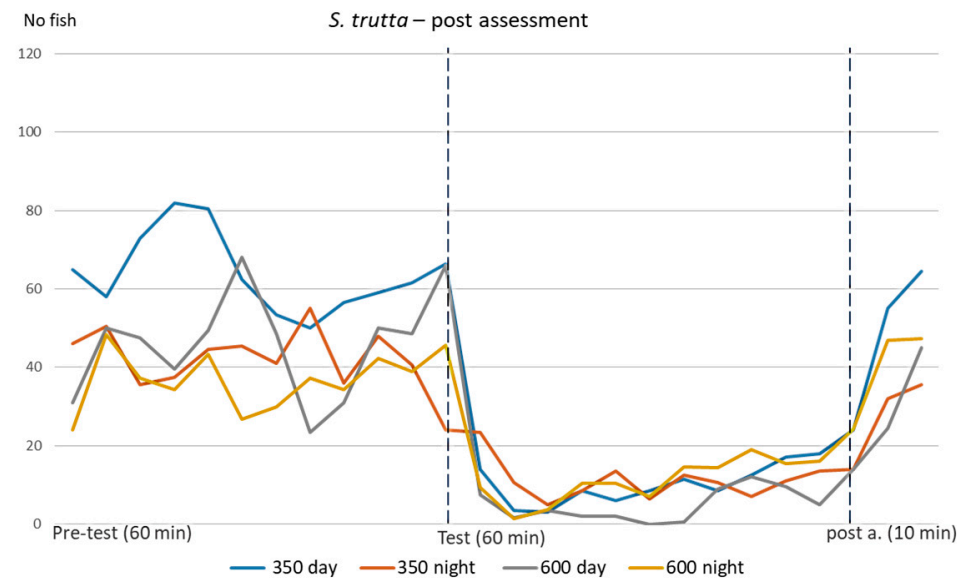

(a)

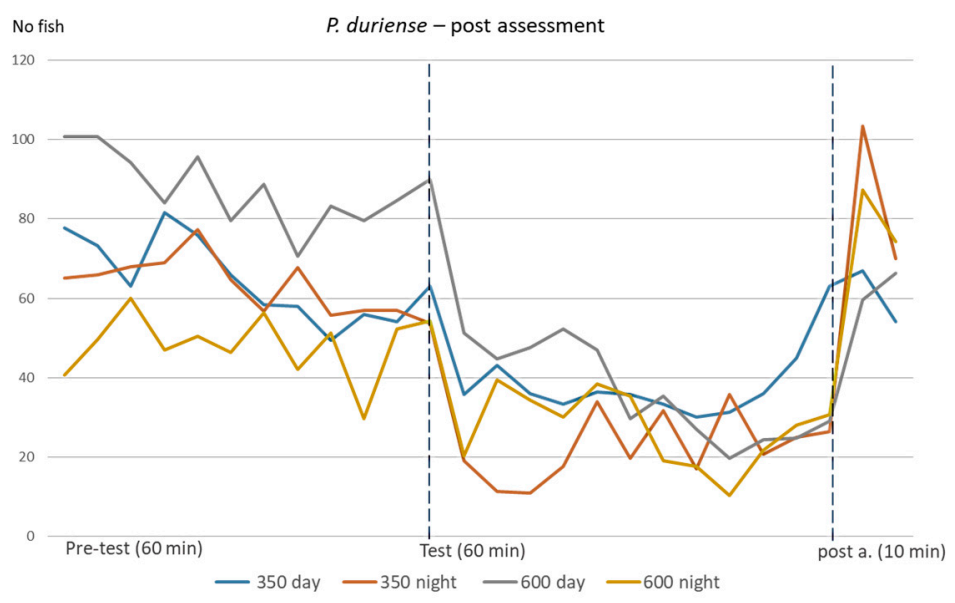

(b)

Figure 2. Fish count (mean values - counting line)) in the tests: 350 flashes/min/day (350 day), 350 flashes/min/night (350 night), 600 flashes/min/day (600 day), 600 flashes/min/night (600 night) with the species: S. trutta (a) and P.duriense (b): pre-test (60 $\mathrm{min})$, test (60 $\mathrm{min}$ ) and post-assessment (10 $\min )$.

\section{Discussion}

Non-physical barriers to guide fish movement can be a useful technique, particularly for the protection of freshwater native species. We studied brown trout to show their behavior $[46,47]$. However, for endemic cyprinids and inclusively for brown trout populations of Iberia, these techniques have not been applied to promote the success of fish downstream migration, through their behavior. Of course, the use of these techniques requires adequate research to determine the specific behavioral responses of each endemic species, since the reaction and response effects to different kind of stimuli remain unknown.

In fact, strobe lights have been successful in altering the behavior of fish and are the most widely underwater light system used for fish deterrent purposes [21,48,49], particularly for salmonid species [24,50-52]. Patrick et al. [53], in experiments with several species of freshwater and estuarine fish, concluded that stroboscopic light has a greater repulsive effect than continuous light. Sager et al. [32] reports that the repulsive efficacy of stroboscopic light in fish depends greatly on the frequency used (flashes/minute), and Coutant [51] adds that most strobe lights tested are set 
at frequencies of 300 flashes/minute or higher. The literature refers to the use of light stimuli in fish with strobe light at various frequencies: 60 flashes/minute [31,54], 86 flashes/minute [36]; 300 flashes/minute $[35,37]$, and considering the evaluation of both the day-time period and the nocturnal period $[29,35,55]$.

As verified in the results of the present study, S. trutta presented in general and particularly during the daytime a greater repulsive behavior than the cyprinid species, namely related to L. bocagei. The difference in repulsive behavior of stroboscopic light, between salmonid and cyprinids is not surprising, since Amaral et al. [55] also observed a superior repulsive behavior of salmonid Chinook salmon in relation to the repulsive behavior of the cyprinid Ptychocheilus oregonensis in the Yakima River (USA). Hansen et al. [56] verified that Chinook salmon, which exhibited a greater repulsive behavior to various light stimuli in the diurnal period and suggests, in its study, that this result may be related to vision and trophic factors. Nevertheless, our results also display clear behavioral differences between fish species, even inside the same family.

Salmonids are predominantly visual predators [57], feeding on small fish, crustaceans, and insects [58] during the day-time $[59,60]$ and crepuscular periods [61], due to the higher ability to detect preys, which may be justified by the higher visual sensitivity during these periods, also observed in the present study for S. trutta $(87.87 \%)$. Relatively to cyprinid species, it was observed for P. duriense, an absolute maximum value of the repulsive behavior $(64.5 \%)$ and L. bocagei $(28.21 \%)$. This result may also be related to the visual capacity, which is variable according to the food strategy, activity cycle (diurnal or nocturnal), water depth, and transparency [62,63]. P. duriense, includes a diet composed of plant material, organic debris, but also by small invertebrates [48]. It is a species that in trophic terms lays between S. trutta and L. bocagei, exhibiting visual capacity for predation, but the adapted mouth (lower corneal lip) allows to feed an algae and invertebrates, which may justify the results of the present study. L. bocagei presented a reduced sensitivity to the luminous stimulus for the two tested frequencies. The low sensitivity may be related to a higher dependence on, less illuminated benthic habitats and, consequently, presents sensory systems well developed like the olfactory and acoustic system [54].

Our results indicate that a repulsive effect of the light stimulus was maintained at a high rate throughout the 1-h of each treatment test, however there seems to be a slight habituation at the end of the test period, in both species, in the 350 flashes/min/day (Figure 2). The post-assessment results seem to reinforce the observation of a low resident effect, because immediately after the end of the light stimulus the fish return to its position similar to the pre-test situation (Figure 2). Mesquita et al. [54] found a habituation behavior of a cyprinid species Danio rerio, after $22.5 \mathrm{~min}$, although it is important to note that they used a low frequency stroboscopic light (60 flashes/minute). However Hamel et al. [20] verified in the tests performed in-situ with strobes lights (360 flashes/minute and 450 flashes/minute) in Lake Oahe, that rainbow smel (Osmerus mordax) showed no habituation phenomena within the $4 \mathrm{~h}$ period of the trials.

The present work contributes to important knowledge of the behavior of native fish populations in the Iberian region, namely related with the objective of its conservation. The results, in general, indicate the high potential of stroboscopic light as a repulsive behavioral stimulus of fish, especially for the species S. trutta and P. duriense. The specific behavioral differences of each species found in the present study, if deepened, can allow the development of selective behavioral systems, of great utility in the safeguarding of these native species. Other trials, with longer periods, should then be carried out with these species, and with invasive species to add information to their habituation and avoidance patterns. Furthermore, this deterrent technology must be tested in natural conditions, using this effect alone or integrated with other behavioral barriers (e.g., bubble curtains, acoustic), in order to safeguard threatened fish species. The development of behavioral barriers specifically adapted to this endemic species of northern Iberia seems to be strategic, particularly in regulated rivers. 
Supplementary Materials: The following are available online at http:/ /www.mdpi.com/2071-1050/11/5/1332/ s1.

Author Contributions: Conceptualization J.J., A.T. and R.C.; methodology J.J., S.N., and A.T.; formal analysis J.J., A.T., and R.C.; investigation, J.J., S.N., and A.T.; resources, J.J. and A.T.; writing-review and editing, J.J., A.T., and R.C.; Supervision, J.J. and A.T.

Funding: The project $n^{\circ}$ 13737: Original Solutions-ENI and CITAB-UTAD was funded project: ANI/QREN/ FEDER. European Investment Funds by FEDER/COMPETE/POCI-Operational Competitiveness and Internationalization Programme, under Project POCI-01-0145- FEDER-006958 and National Funds by FCTPortuguese Foundation for Science and Technology, under the project UID/AGR/04033/2013.

Acknowledgments: The present study was technically supported by Instituto da Conservação da Natureza e Florestas (ICNF-Departamento Norte), namely the facilities at the fish farm "Posto Aquicola de Castrelos", for the execution of the experimental design.

Conflicts of Interest: The authors declare no conflict of interest.

\section{References}

1. Hermoso, V.; Clavero, M. Threatening processes and conservation management of endemic freshwater fish in the Mediterranean basin: A review. Mar. Freshw. Res. 2011, 62, 244-254. [CrossRef]

2. Dudgeon, D.; Arthington, A.H.; Gessner, M.O.; Kawabata, Z.-I.; Knowler, D.J.; Lévêque, C.; Naiman, R.J.; Prieur-Richard, A.-H.; Soto, D.; Stiassny, M.L. Freshwater biodiversity: Importance, threats, status and conservation challenges. Biol. Rev. 2006, 81, 163-182. [CrossRef] [PubMed]

3. Baras, E.; Lucas, M.C. Impacts of man's modifications of river hydrology on the migration of freshwater fishes: A mechanistic perspective. Int. J. Ecohydrol. Hydrobiol. 2001, 1, 291-304.

4. Noatch, M.R.; Suski, C.D. Non-physical barriers to deter fish movements. Environ. Rev. 2012, $20,71-82$. [CrossRef]

5. Pitcher, T.J. Population Dynamics and Schooling Behaviour in the Minnow. Ph.D. Thesis, University of Oxford, Oxford, UK, 1971.

6. Fredrich, F. Preliminary studies on daily migration of chub (Leuciscus cephalus) in the Spree River. In Underwater Biotelemetry, Proceedings of the First Conference and Workshop on Fish Telemetry in Europe, Liège, Belgium, 4-6 April 1995; University of Liège: Liège, Belgium, 1995.

7. Lucas, M.; Baras, E. Migration of Freshwater Fishes; John Wiley \& Sons: New York, NY, USA, 2008.

8. Pires, D.F.; Pires, A.M.; Collares-Pereira, M.J.; Magalhães, M.F. Variation in fish assemblages across dry-season pools in a Mediterranean stream: Effects of pool morphology, physicochemical factors and spatial context. Ecol. Freshw. Fish 2010, 19, 74-86. [CrossRef]

9. Cabral, M.J.; Almeida, J.; Almeida, P.R.; Dellinger, T.; Ferrand de Almeida, N.; Oliveira, M.E.; Palmeirim, J.M.; Queirós, A.I.; Rogado, L.; Santos-Reis, M. Livro Vermelho dos Vertebrados de Portugal; Instituto da Conservação da Natureza: Lisboa, Portugal, 2005.

10. Teixeira, A.; Cortes, R.M. PIT telemetry as a method to study the habitat requirements of fish populations: Application to native and stocked trout movements. In Developments in Fish Telemetry; Springer: Berlin/Heidelberg, Germany, 2007; pp. 171-185. [CrossRef]

11. Gosset, C.; Rives, J.; Labonne, J. Effect of habitat fragmentation on spawning migration of brown trout (Salmo trutta L.). Ecol. Freshw. Fish 2006, 15, 247-254. [CrossRef]

12. Santos, J.M.; Reino, L.; Porto, M.; Oliveira, J.; Pinheiro, P.; Almeida, P.R.; Cortes, R.; Ferreira, M.T. Complex size-dependent habitat associations in potamodromous fish species. Aquat. Sci. 2011, 73, 233-245. [CrossRef]

13. Clavero, M. Shifting baselines and the conservation of non-native species. Conserv. Biol. 2014, 28, 1434-1436. [CrossRef]

14. Ovidio, M.; Philippart, J.-C. Movement patterns and spawning activity of individual nase Chondrostoma nasus (L.) in flow-regulated and weir-fragmented rivers. J. Appl. Ichthyol. 2008, 24, 256-262. [CrossRef]

15. Abernethy, C.S.; Amidan, B.G.; Cada, G.F. Simulated Passage through a Modified Kaplan Turbine Pressure Regime: A Supplement to "Laboratory Studies of the Effects of Pressure and Dissolved Gas Supersaturation on Turbine-Passed Fish"; Pacific Northwest National Lab. (PNNL): Richland, WA, USA, 2002.

16. Rytwinski, T.; Algera, D.A.; Taylor, J.J.; Smokorowski, K.E.; Bennett, J.R.; Harrison, P.M.; Cooke, S.J. What are the consequences of fish entrainment and impingement associated with hydroelectric dams on fish productivity? A systematic review protocol. Environ. Evid. 2017, 6, 8. [CrossRef] 
17. Čada, G.F.; Coutant, C.C.; Whitney, R.R. Development of Biological Criteria for the Design of Advanced Hydropower Turbines; DOE/ID-10578; US Department of Energy, Idaho Operations Office: Idaho Falls, ID, USA, 1997.

18. Čada, G.F. The development of advanced hydroelectric turbines to improve fish passage survival. Fisheries 2001, 26, 14-23. [CrossRef]

19. Hydro, B.C. Developing Measures for the Aquatic Habitat Attribute in BC Hydro's 2005 Integrated Electricity Plan; Ecofish Research Ltd.: Courtenay, BC, Canada, 2005.

20. Hamel, M.J.; Brown, M.L.; Chipps, S.R. Behavioral responses of rainbow smelt to in situ strobe lights. N. Am. J. Fish. Manag. 2008, 28, 394-401. [CrossRef]

21. Kim, J.; Mandrak, N.E. Effects of strobe lights on the behaviour of freshwater fishes. Environ. Biol. Fishes 2017, 100, 1427-1434. [CrossRef]

22. Sand, O.; ENGER, P.; Karlsen, H.E.; Knudsen, F.R. To Intense Infrasound In Juvenile Salmonids. In Proceedings of the American Fisheries Society Symposium, Phoenix, AZ, USA, 20-21 August 2001; Volume 26, pp. 183-193.

23. Maes, J.; Turnpenny, A.W.H.; Lambert, D.R.; Nedwell, J.R.; Parmentier, A.; Ollevier, F. Field evaluation of a sound system to reduce estuarine fish intake rates at a power plant cooling water inlet. J. Fish Biol. 2004, 64, 938-946. [CrossRef]

24. Maiolie, M.A.; Harryman, B.; Ament, B. Response of free-ranging kokanee to strobe lights. In Proceedings of the Behavioral Technologies for Fish Guidance: American Fisheries Society Symposium, Baltimore, MD, USA, 20-23 May 2001; p. 27.

25. Königson, S.; Fjälling, A.; Lunneryd, S.-G. Reactions in individual fish to strobe light. Field and aquarium experiments performed on whitefish (Coregonus lavaretus). Hydrobiologia 2002, 483, 39-44. [CrossRef]

26. Sparks, R.E.; Barkley, T.L.; Creque, S.M.; Dettmers, J.M.; Stainbrook, K.M. Evaluation of an electric fish dispersal barrier in the Chicago Sanitary and Ship Canal. In American Fisheries Society Symposium; American Fisheries Society: Bethesda, MD, USA, 2010; Volume 74.

27. Clarkson, R.W. Effectiveness of electrical fish barriers associated with the Central Arizona Project. N. Am. J. Fish. Manag. 2004, 24, 94-105. [CrossRef]

28. Kates, D.; Dennis, C.; Noatch, M.R.; Suski, C.D. Responses of native and invasive fishes to carbon dioxide: Potential for a nonphysical barrier to fish dispersal. Can. J. Fish. Aquat. Sci. 2012, 69, 1748-1759. [CrossRef]

29. Da Silva, L.G.M. Estudo de Sistemas para Repulsão de Peixes Como Alternativas de Mitigação de Impacto Ambiental em Usinas Hidrelétricas e Canais para Abastecimento de Água. Ph.D. Thesis, UFMG, Belo Horizonte, Brzail, 2010.

30. Ruebush, B.C. In-situ Tests of Sound-Bubble-Strobe Light Barrier Technologies to Prevent the Range Expansions of Asian Carp. 2011. Available online: http://hdl.handle.net/2142/26112 (accessed on 24 February 2019).

31. Stewart, H.A.; Wolter, M.H.; Wahl, D.H. Laboratory investigations on the use of strobe lights and bubble curtains to deter dam escapes of age-0 Muskellunge. N. Am. J. Fish. Manag. 2014, 34, 571-575. [CrossRef]

32. Sager, D.R.; Hocutt, C.H.; Stauffer, J.R., Jr. Estuarine fish responses to strobe light, bubble curtains and strobe light/bubble-curtain combinations as influenced by water flow rate and flash frequencies. Fish. Res. 1987, 5, 383-399. [CrossRef]

33. Johnson, R.L.; Simmons, M.A.; McKinstry, C.A.; Simmons, C.S.; Cook, C.B.; Brown, R.S.; Tano, D.K.; Thorsten, S.L.; Faber, D.M.; Lecaire, R. Strobe Light Deterrent Efficacy Test and Fish Behavior Determination at Grand Coulee Dam Third Powerplant Forebay; Pacific Northwest National Lab. (PNNL): Richland, WA, USA, 2005.

34. Lythgoe, J.N. Ecology of Vision; Clarendon Press: Oxford, UK, 1979.

35. Puckett, K.J.; Anderson, J.J. Behavioral Responses of Juvenile Salmonids to Strobe and Mercury Lights; Fisheries Research Institute: Seattle, WA, USA, 1987.

36. Richards, N.S.; Chipps, S.R.; Brown, M.L. Stress response and avoidance behavior of fishes as influenced by high-frequency strobe lights. N. Am. J. Fish. Manag. 2007, 27, 1310-1315. [CrossRef]

37. Silva, L.G.M.; Martinez, C.B.; Formagio, P. Uso de luz estroboscópica para repulsão de peixes de áreas de risco em usinas hidrelétricas. SIMPÓSIO Bras. SOBRE PEQUENAS E MÉDIAS CENTRAIS HIDRELÉTRICAS 2006, 5, 3-6.

38. Ovidio, M.; Parkinson, D.; Philippart, J.-C.; Baras, E. Multiyear homing and fidelity to residence areas by individual barbel (Barbus barbus). Belg. J. Zool. 2007, 137, 183-190. 
39. Benitez, J.-P.; Ovidio, M. The influence of environmental factors on the upstream movements of rheophilic cyprinids according to their position in a river basin. Ecol. Freshw. Fish 2018, 27, 660-671. [CrossRef]

40. Costa, M.J.; Boavida, I.; Almeida, V.; Cooke, S.J.; Pinheiro, A.N. Do artificial velocity refuges mitigate the physiological and behavioural consequences of hydropeaking on a freshwater Iberian cyprinid? Ecohydrology 2018, 11, e1983. [CrossRef]

41. Coutant, C.C.; Whitney, R.R. Fish behavior in relation to passage through hydropower turbines: A review. Trans. Am. Fish. Soc. 2000, 129, 351-380. [CrossRef]

42. Taylor, R.M.; Pegg, M.A.; Chick, J.H. Response of bighead carp to a bioacoustic behavioural fish guidance system. Fish. Manag. Ecol. 2005, 12, 283-286. [CrossRef]

43. Vetter, B.J.; Cupp, A.R.; Fredricks, K.T.; Gaikowski, M.P.; Mensinger, A.F. Acoustical deterrence of silver carp (Hypophthalmichthys molitrix). Biol. Invasions 2015, 17, 3383-3392. [CrossRef]

44. Schilt, C.R. Developing fish passage and protection at hydropower dams. Appl. Anim. Behav. Sci. 2007, 104, 295-325. [CrossRef]

45. Perry, R.W.; Romine, J.G.; Adams, N.S.; Blake, A.R.; Burau, J.R.; Johnston, S.V.; Liedtke, T.L. Using a non-physical behavioural barrier to alter migration routing of juvenile chinook salmon in the sacramento-san joaquin river delta. River Res. Appl. 2014, 30, 192-203. [CrossRef]

46. Nedwell, J.R.; Turnpenny, A.W.; Lovell, J.M.; Edwards, B. An investigation into the effects of underwater piling noise on salmonids. J. Acoust. Soc. Am. 2006, 120, 2550-2554. [CrossRef] [PubMed]

47. Vowles, A.S.; Kemp, P.S. Effects of light on the behaviour of brown trout (Salmo trutta) encountering accelerating flow: Application to downstream fish passage. Ecol. Eng. 2012, 47, 247-253. [CrossRef]

48. Popper, A.N.; Carlson, T.J. Application of sound and other stimuli to control fish behavior. Trans. Am. Fish. Soc. 1998, 127, 673-707. [CrossRef]

49. Bullen, C.R.; Carlson, T.J. Non-physical fish barrier systems: Their development and potential applications to marine ranching. Rev. Fish Biol. Fish. 2003, 13, 201-212. [CrossRef]

50. Nemeth, R.S.; Anderson, J.J. Response of juvenile coho and chinook salmon to strobe and mercury vapor lights. N. Am. J. Fish. Manag. 1992, 12, 684-692. [CrossRef]

51. Coutant, C.C. Integrated, multi-sensory, behavioral guidance systems for fish diversion. In Behavioral Technologies for Fish Guidance: American Fisheries Society Symposium; American Fisheries Society: Bethesda, MD, USA, 2001; p. 105.

52. Taft, E.P.; Dixon, D.A.; Sullivan, C.W. Electric Power Research Institute's (EPRI) research on behavioral technologies. In Behavioral Technologies for Fish Guidance: American Fisheries Society Symposium; American Fisheries Society: Bethesda, MD, USA, 2001; p. 115.

53. Patrick, P.H.; Christie, A.E.; Sager, D.; Hocutt, C.; Stauffer, J., Jr. Responses of fish to a strobe light/air-bubble barrier. Fish. Res. 1985, 3, 157-172. [CrossRef]

54. De Oliveira Mesquita, F.; Godinho, H.P.; de Azevedo, P.G.; Young, R.J. A preliminary study into the effectiveness of stroboscopic light as an aversive stimulus for fish. Appl. Anim. Behav. Sci. 2008, 111, $402-407$. [CrossRef]

55. Amaral, S.V.; Winchell, F.C.; Pearsons, T.N. Behavioral Technologies for Fish Guidance: American Fisheries Society Symposium; American Fisheries Society: Bethesda, MD, USA, 2001; pp. 125-144.

56. Hansen, M.J.; Cocherell, D.E.; Cooke, S.J.; Patrick, P.H.; Sills, M.; Fangue, N.A. Behavioural guidance of Chinook salmon smolts: The variable effects of LED spectral wavelength and strobing frequency. Conserv. Physiol. 2018, 6, coy032. [CrossRef] [PubMed]

57. Ruetz III, C.R.; Hurford, A.L.; Vondracek, B. Interspecific interactions between brown trout and slimy sculpin in stream enclosures. Trans. Am. Fish. Soc. 2003, 132, 611-618. [CrossRef]

58. Kottelat, M.; Freyhof, J. Handbook of European Freshwater Fishes; Publications Kottelat: Cornol, Switzerland, 2007.

59. McIntosh, A.R.; Townsend, C.R. Contrasting predation risks presented by introduced brown trout and native common river galaxias in New Zealand streams. Can. J. Fish. Aquat. Sci. 1995, 52, 1821-1833. [CrossRef]

60. Fraser, N.H.C.; Metcalfe, N.B. The costs of becoming nocturnal: Feeding efficiency in relation to light intensity in juvenile Atlantic salmon. Funct. Ecol. 1997, 11, 385-391. [CrossRef]

61. Bachman, R.A.; Reynolds, W.W.; Casterlin, M.E. Diel locomotor activity patterns of wild brown trout (Salmo trutta L.) in an electronic shuttlebox. Hydrobiologia 1979, 66, 45-47. [CrossRef] 
62. Muntz, W.R. Visual adaptations to different light environments in Amazonian fishes. Rev. Can. Biol. Exp. 1982, 41, 35-46. [PubMed]

63. Pankhurst, N.W. The relationship of ocular morphology to feeding modes and activity periods in shallow marine teleosts from New Zealand. Environ. Biol. Fishes 1989, 26, 201-211. [CrossRef] 